\title{
EFEKTIVISTAS MEDIA VIDIO TUTORIAL DALAM MENINGKATKAN KETERAMPILAN LIFE SKILL MEIMBUAT SELAI DARI ALOE VERA BAGI ANAK TUNARUNGU DI SLB PERWARI PADANG (Pre Exsperimental Design kelas B di SLB Perwari Padang)
}

\author{
Putry Fauziyyah ${ }^{1}$, Armaini² \\ Universitas Negeri Padang
}

\begin{abstract}
This study discusses the effectiveness of video tutorial media in improving the life skills of making aloe vera jam for deaf children. The subjects of this study were five deaf children. This study used a pre-experimental design method, the abilities assessed by the pretest and posttest designs were processed and compared using the Wilcoxon Sign Rank Test.

Based on the results of the pretest and posttest, it is known that the pretest average value is 24.60 and the posttest average value is 84 . The average value is then processed to find the difference using the Wilcoxon Sign Rank Test. From the results of data analysis obtained Zhitung $=-2.032$ with probability or Asymp Sig (2-tailed) $=0.42$ at a significant level of $5 \%$ and $\alpha=0.05$. The alternative hypothesis is accepted because Zhitung > Asymp. Sig. (2-tailed). So it can be concluded that the video tutorial media is effective in improving the life skills of making aloe vera jam for deaf children at SLB Perwari, Padang.
\end{abstract}

Keywords: Life skills, making aloe vera, deaf

\section{PENDAhuluaN}

Pendidikan merupakan suatu usaha yang dilakukan untuk meningkatkan kemampuan atau potensi diri dalam menjalani kehidupan secara mandiri dan dapat berperan aktif dalam lingkungan kehidupannya., yang secara sadar berstruktur untuk meningkatkan perkembangan anak agar lebih progresif baik dalam segi perkembangan akademik maupun perkembangan emosi sosialnya agar mereka dapat berinteraksi dengan lingkungan sekitarnya.

Tunarungu adalah seseorang yang mengalami gangguan pendengaran yang meliputi seluruh gradasi ringan, sedang, dan sangat berat yang dalam hal ini dapat dikelompokan menjadi dua golongan, yaitu kurang dengar dan tuli yang menyebabkan terganggunya proses perolehan informasi atau bahasa sebagai alat komunikasi. Pada dasarnya intelegensi anak tunarugu tidak terganggu, namun meskipun demikian, kita juga perlu juga membekali dengan keterampilan untuk kemandirian mereka kemudian hari, terkhususnya pada pembuatan selai dari aloe vera. 
Pada penelitian ini anak akan diajarkan cara pembuatan selai dari aloe vera secara terperinci dan berkelanjutan, sehingga nanti hasilnya dapat membantu untuk keterampilan kemandirian pada masa depan anak tunarungu tersebut,sehingga anak tunarungu tersebut bisa hidup mandiri dan tidak ketergantungan pada keluarga.

Berdasarkan studi pendahuluan yang dilakukan peneliti selama praktek magang di SLB Perwari Padang, peneliti melakukan observasi, secara lansung peneliti menemukan terdapat sebuah kelas khusus keterampilan untuk anak tunarungu berjumlah lima orang yang terdiri dari satu anak perempuan dan empat laki-laki. Dimana kelas tersebut mempelajari keterampilan Life Skill yang sudah ada dikurikulum yaitu tata boga, kerajinan tangan dan lainnya. Setelah itu peneliti juga mewawancarai kepala sekolah, peneliti menanyakan bagaimana pelaksanaan pembelajaran keterampilan tata boga disekolah tersebut, lalu kepala sekolah menjelaskan bahwa pelajaran tersebut kurang berjalan dengan baik dikarenakan siswa yang kurang berminat pada saat pembelajaran keterampilan tata boga. Selain itu peneliti juga melakukan wawancara kepada guru kelas yang mengajarkan keterampilan tata boga dikelas tersebut, peneliti menanyakan hal-hal penting berkisaran pembelajaran keterampilan tata boga di kelas tersebut kepada guru. Guru tersebut menjelaskan bahwa kegiatan pembelajaran dilakukan tiga kali dalam seminggu didalam jam pembelajaran, yaitu tepatnya hari senin, rabu, kamis pada jam pembelajaran.

Selama praktek magang itu juga peneliti melakukan wawancara kepada guru kelas keterampilan tersebut tentang apa-apa saja keterampilan yang sudah dilakukan anak selama masa disekolah, guru kelas tersebut menjawab bahwa kelas khusus keterampilan ini biasanya hanya diberikan keterampilan yang sudah dipelajari dan sudah ada dikurikulum sekolah contohnya keterampilan tata boga, tata busana dan kerajinan tangan.

Kemudian dalam hal memberikan pembelajaran keterampilan tersebut guru kelas biasanya hanya menggunakan metode ceramah dan demonstrasi sehingga siswa tampak bosan dan kurang memperdulikan guru seperti yang sudah disampaikan kepala sekolah sehingga hasil karya siswa kurang maksimal. Kemudian dalam hal keterampilan yang menghasilkan olahan memasak tata boga dari bahan-bahan yang ada dilingkungan sekitar ternyata sekolah belum melakukannya, peneliti melakukan wawancara lagi kepada guru kelas keterampilan tersebut, peneliti menanyakan keinginan guru kelas tersebut untuk keterampilan yang ada dikelasnya, kemudian guru kelas tersebut mengatakan bahwa beliau ingin adanya sebuah inovasi keterampilan baru yang mudah dibuat serta alat dan bahan untuk membuat keterampilan tersebut mudah didapat yang bahan-bahannya ada dilingkungan sekitar yang belum dimanfaatkan dengan baik oleh masyarakat yang nantinya bisa diolah anak untuk menabah wawasan dan ilmunya dalam sebuah keterampilan agar anak terampil dalam membuat suatu karya berharga. Tujuannya yaitu anak tunarungu dikelas keterampilan di SLB Perwari Padang tersebut dapat menyalurkan keinginan mereka membuat sebuah produk yang mudah dibuat dengan cara yang sederhana. Sehingga dengan beragamnya keterampilan yang dimiliki tunarungu 
akan membantu mereka untuk melangsungkan kehidupan mereka kedepannya.Sehubungan dengan permasalahan diatas, peneliti mencoba memberikan keterampilan baru dikelas keterampilan tersebut dengan cara mudah dibuat serta alat dan bahannya mudah didapat tanpa harus mengeluarkan biaya yang mahal serta dengan metode yang belum dilaksanakan di kelas tersebut sehingga menghasilkan produk yang layak jual dan produk tersebut bisa digunakan untuk kehidupan sehari-hari.

Merujuk pada permasalahan yang ditemukan, peneliti tertarik meneliti sebuah keterampilan Life Skill yaitu pembuatan Selai dari aloe vera bagi anak tunarungu. Menurut guru kelas pembuatan selai aloe vera/ lidah buaya bagi anak tunarungu belum pernah diajarkan. Sedangkan kurikulum yang digunakan oleh SLB Perwari Padang yaitu kurikulum 13, yang pembelajaran keterampilannya termasuk ke dalam SBDP (seni budaya dan prakarya). Untuk mata pelajaran pendidikan keterampilan disesuaikan dengan tingkat usia siswa atau peserta didik belum memasuki usia kerja maka dikemas dengan kelompok SBDP. Untuk mata pelajaran Life Skill dengan alokasi aktu sebanyak 26 jam pelajaran. Serta materi yang disampaikan secara umum terdiri dari kerajinan, budidaya, dan juga pengolahan. Untuk ruang lingkup dari kerajinan meliputi kerajinan tangan dari berbagai bahan, ruang lingkup budidaya meliputi perikanan, pertenakan dan pertanian, sedangkan ruang lingkup dari pengolahan meliputi tata boga atau memasak suatu bahan untuk diolah.

\section{METODOLOGI PENELITIAN}

Pada penelitian ini penulis menggunakan jenis penelitian metode eksperimen. Metode ini dipakai untuk mengetahui apakah media Vidio Tutorial efektif digunakan dalam meningkatkan keterampilan Life Skill membuat selai dari aloe vera bagi anak tunarungu di SLB Perwari Padang. Tujuan dari penelitian ini adalah untuk menemukan pengaruh dari Vidio Tutorial terhadap peningkatan keterampilan Life Skill anak tunarungu.Verifikasi hasilnya diperoleh dengan membandingkan antara sebelum diberi perlakuan dengan sesudah diberi perlakuan.

Jenis desain eksperimen yang digunakan adalah jenis desain one group pre test and post test design. Dalam penelitian ini ada dua kali observasi yaitu ketika sebelum diberikan perlakuan atau disebut pretest $\left(\mathrm{O}_{1}\right)$, dan ketika setelah diberi perlakuan disebut posttest $\left(\mathrm{O}_{2}\right)$. Sehingga nanti akan terlihat perbandingan atau perbedaan sebelum diberikan perlakuan dengan setelah diberikan perlakuan. Berikut penjelasan pelaksanaan eksperimen menurut (Yusuf, 2007) : 


\begin{tabular}{|ccc|}
\hline Pretest & Perlakuan & Postest \\
01 & $\mathrm{X}$ & 02 \\
\hline
\end{tabular}

\section{Pola: O1 X O2}

Keterangan dibawah ini

O1 : Pretest, melihat kondisi awal siswa sebelum diberi perlakuan dalam membuat keterampilan Life Skill membuat selai dari aloe vera.

$\mathrm{X}$ : Perlakuan atau treatment dengan menggunakan media Vidio Tutorial.

O2 : Postest, melihat hasil pemahaman siswa dalam keterampilan Life Skill membuat selai dari aloe vera melalui media Vidio Tutorial.

\section{KAJIAN TEORI}

Media vidio tutorial merupakan media yang digunakan sebagai arahan atau petunjuk untuk seseorang yang berbentuk vidio yang dapat menjelaskan step demi step cara melakukan sesuatu yang diinginkan agar sesuai dan juga benar. Menurut (Munir, 2012), video yaitu alat atau media yang dapat mempertunjukan benda-benda nyata. Sedangkan tutorial adalah sebuah informasi yang disajikan dalam bentuk tayangan-tayangan disertai dengan penjelasannya. Video tutorial adalah sebuah teknologi yang merekam, menangkap dan memproses suatu informasi yang berupa video berisikan materi pembelajaran yang akan disampaikan kepada peserta didik (Desrianti,D.I., Rahardja, U,. \&Mulyani,2012).

Life skill merupakan pendidikan kecakapan hidup yang memberikan bekal dasar dan latihan yang dilakukan secara benar kepada peserta didik yang tentunya akan berkaitan dengan nilai-nilai yang ada didalam kehidupan sehari-hari agar yang peserta didik mampu, sanggup, dan terampil menjalankan kehidupan nantinya dengan menjaga kelangsungan hidup dan menyesuaikan dengan perkembangan di masa yang akan datang. Menurut Rais Saembodo dalam Wira Kurnia S (2006) Mengatakan kecakapan, keterampilan ( skill ) menunjukan sesuatu kecakapan atau keterampilan in di peroleh melalui latihan atau pengalaman. Sasaran utama proses pengembangan sumber daya manusia dapat diarahkan pada usaha membina agar seoptimal mungkin.

Menurut Mega Iswari (2007: 57) istilah tunarungu ditunjukkan pada anak atau individu yang mengalami kehilangan kemampuan mendengar, baik kehilangan kemampuan sebagian maupun kehilangan kemampuan mendengar sama sekali.Sedangkan menurut (Mangunsong, 2014) yang dimaksud dengan tunarungu adalah 
mereka yang pendengaranya tidak berfungsi sehingga mereka membutuhkan pelayanan pendidikan khusus.

\section{HASIL PENELITIAN DAN PEMBAHASAN}

Dalam penelitian ini terjadi peningkatan dalam membuat selai aloe vera dari hasil perbandingan pretest dan posttest yang sudah peneliti lakukan. Pretest dilakukan satu kali untuk menentukan kemampuan awal anak dalam membuat Selai aloe vera. Selanjutnya dilakukan treatment dengan menggunakan media video tutorial yang dilakukan sebanyak lima kali pertemuan. Untuk penilaian akhir penulis melakukan posttes. Pada tahap posttes menentukan pengetahuan anak setelah diberi perlakuan. Jika dibandingkan pretest dan posttes terlihat perbandingan yang meningkat pengetahuan anak dalam keterampilan Life Skill membuat selai dari aloe vera. Dari hasil uji Wilcoxon Sign Rank Test dimana Zhitung =-2.032 dan Asymp sig. (2-tailed)=0.042. maka > Asymp. Sig. (2-tailed). dengan demikian Ho ditolak dan Ha diterima.

\section{SIMPULAN}

Berdasarkan hasil penelitian dan pembahasan, maka dapat ditarik kesimpulan bahwa media video tutorial Efektif digunakan untuk meningkatkan keterampilan Life Skill membuat Selai dari aloe vera bagi anak tunarungu. Hal ini terbukti dari hasil perhitungan data yang diperoleh dengan menggunakan uji Wilcoxon Sign Rank Test dimana 2,032 dan Asym sig. (2tailed) $=0,42$, berarti Asymp sig. (2-tailed) dengan demikian Ho ditolak dan Ha diterima.

\section{DAFTAR PUSTAKA}

Iswari, M. (2008). Kecakapan Hidup bagi Anak Berkebutuhan Khusus. padang: UNP Press.

Mangunsong, F. (2014). Psikologi dan Pendidikan Anak Berkebutuhan Khusus. depok: LPSP3 UI.

Yusuf, M. (2007). Metodologi Penelitian. Padang: UNP Press.

Desrianti, D. I., Rahardja, U,. \& Mulyani, R. (2012). Audio Visual As One Of The Teaching Resources On Ilearning. Ccit Jurnal, 5(2), 124-144.

Wira Kurnia S," Pendidikan Keterampilan Sebagai Upaya Pemberdayaan Siswa”, skripsi sarjana pendidikan, (Malang: Perpustakaan UIN Maulana Malik Ibrahim, 2006). 